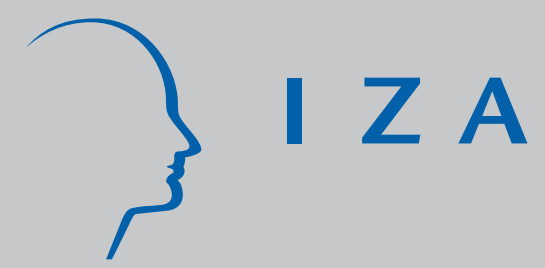

IZA DP No. 8111

Is Religion Associated with Entrepreneurial Activity?

Andrew Henley

April 2014

Forschungsinstitut zur Zukunft der Arbeit Institute for the Study of Labor 


\title{
Is Religion Associated with Entrepreneurial Activity?
}

\author{
Andrew Henley \\ Aberystwyth University \\ and IZA
}

\author{
Discussion Paper No. 8111 \\ April 2014
}

IZA
P.O. Box 7240
53072 Bonn
Germany

Phone: +49-228-3894-0

Fax: +49-228-3894-180

E-mail: iza@iza.org

Any opinions expressed here are those of the author(s) and not those of IZA. Research published in this series may include views on policy, but the institute itself takes no institutional policy positions. The IZA research network is committed to the IZA Guiding Principles of Research Integrity.

The Institute for the Study of Labor (IZA) in Bonn is a local and virtual international research center and a place of communication between science, politics and business. IZA is an independent nonprofit organization supported by Deutsche Post Foundation. The center is associated with the University of Bonn and offers a stimulating research environment through its international network, workshops and conferences, data service, project support, research visits and doctoral program. IZA engages in (i) original and internationally competitive research in all fields of labor economics, (ii) development of policy concepts, and (iii) dissemination of research results and concepts to the interested public.

IZA Discussion Papers often represent preliminary work and are circulated to encourage discussion. Citation of such a paper should account for its provisional character. A revised version may be available directly from the author. 


\section{ABSTRACT}

\section{Is Religion Associated with Entrepreneurial Activity?}

This paper provides a quantitative investigation of the strength of the potential relationship between entrepreneurial activity and religious affiliation. The relationship between religion and economic development has attracted recent attention. A positive association may indicate that religion raises the social acceptability of entrepreneurial activity, by inculcating incentives to accumulate wealth and acquire personal responsibility, as well as providing social capital and may be particularly effective where state governance systems are weak. Institutionalist perspectives suggest that religious institutions may support definition of property rights. Economic benefits flow through reduced transactions costs. This paper engages these discussions in order to present a preliminary empirical investigation of the relationships which may exist across national boundaries between religion and entrepreneurship. Definitions of entrepreneurship are taken from the Global Entrepreneurship Monitor (GEM) studies for 2011 and 2012, focusing on the individual rather than on the business venture. Recent data on religious affiliation across countries are used to construct various measures of religious activity and diversity. Preliminary findings suggest, in particular, a significant association between GEM indicators and evangelical-pentecostal-charismatic Christian affiliation. The strength of these associations is offset by state regulation of religion. These findings suggest that attention needs to be paid to the potentially important role that certain forms of religion might play is providing a supportive cultural environment for entrepreneurship. They also suggest that policy-makers may wish to pay closer attention to the potentially supportive role that certain religious organizations might play in new business formation.

\section{NON-TECHNICAL SUMMARY}

This paper identifies a positive association between religious affiliation and levels of entrepreneurial activity across nations, particularly focusing on new forms of Christianity. This relationship holds even when allowing for the stage of development of a country. It also finds that where governments regulate freedom of religious affiliation, levels of entrepreneurial activity may be damaged, and suggests that religious institutions may provide a valuable supporting institutional context for entrepreneurship and therefore economic development.

JEL Classification: L26, M13, O43, Z12

Keywords: entrepreneurship, economic development, religion

Corresponding author:

Andrew G. Henley

School of Management and Business

Aberystwyth University

Llanbadarn

Aberystwyth, SY23 3AL

United Kingdom

E-mail: a.g.henley@aber.ac.uk 


\section{Introduction}

This paper is concerned with the important domain of religion and its relation to entrepreneurial activity. A small but developing literature in the field of entrepreneurship research addresses important questions of the relationship between culture and entrepreneurial activity, and indicates that these questions are beginning to receive scholarly attention. Previous researchers have noted that questions of the relationship of culture to economic development and entrepreneurship have spanned scholarly effort across range of disciplinary perspectives over a considerable period of time. These include economics (Schumpeter, 1934; McCloskey, 2007); sociology (most notably Weber, 1905) and social psychology (McClelland, 1961). However it has also been noted that research on the entrepreneurship-culture nexus has largely focused on Hofstede's dimensions of national culture (Hofstede, 1980) and has to some extent ignored other domains, including that of religion (Hayton et al., 2002). As one leading sociologist of religion notes: "religion is not something that can be safely or sensibly relegated either to the past or to the edge" (Davie, 2007, p. 1).

While active participation in religious activity may have been falling in some parts of the world, notably in the advanced economies of western Europe, in other areas, such as Africa and Asia, it appears to have been on the rise. Furthermore changes in participation in religious practice need not necessarily imply a change in the extent to which underlying religious values influence human behaviour. Broad information on religious affiliation may also mask considerable variation in culture and values within particular religions, and even within religious denominations, and this variation in turn may have implications for any potential association with economic behaviour. In short we know rather little about whether and how religion influences entrepreneurial activity. 
The present paper seeks to engage with and assess the discussions around the religionentrepreneurship nexus. In support of this it presents a preliminary macro-level empirical investigation of the relationships that may exist across national boundaries between religious adherence and rates of entrepreneurial activity. Definitions and measures of entrepreneurship are taken from the Global Entrepreneurship Monitor studies, focusing on the individual rather than on the business venture. Business organizations themselves may, even in their early stages of development, acquire particular "personality" in terms of values and culture, and religious beliefs and practices are strongly influenced by collective and societal patterns. On the other hand it is individuals who hold to particular religious affiliations and behaviours, and therefore may bring those to bear on choices about business venturing activity. But set against this, societal and culture milieux may play an important role in framing those religious affiliations and behaviours. Such influences may also cut across traditional lines of religious structure and organization. As well as focusing on potential differences in the relation between particular world religious groups and levels of entrepreneurial activity, the paper focuses on sub-divisions within Christian religious affiliation and the extent to which these map on to or transcend denominational groupings. The paper focuses particularly on the rapidly growing evangelical, charismatic and pentecostal forms of Christianity which transcend traditional sectarian and denominational boundaries. The data suggest that there may exist a significant association between this form of religious expression and rates of entrepreneurship, and one that does not appear to be present in potential associations with other groupings and expressions of religion. The key conclusions to emerge from this analysis support this, and suggest that is it robust to controlling for the mediating impact of levels and rates of general economic development. However entrepreneurial activity appears to be negatively associated with higher levels of government regulation of religion, pointing 
to the importance of a liberal environmental to allowing any positive benefits of religious activity to filter through to entrepreneurship.

The remainder of the paper is structured as follows. Section 2 provides a review of the state of the current literature. Section 3 develops the key research questions addressed in the paper, and describes the methodology and secondary data sources used. Section 4 presents findings. Section 5 provides a discussion of these findings, and section 6 provides a brief conclusion.

\section{Background and research questions}

The most comprehensive review of the relationship between culture and entrepreneurship highlights three research themes (Hayton et al. 2002). The first of these addresses the relationship between national culture and aggregate indicators of entrepreneurial activity (Davidsson, 1995; Davidsson and Wiklund, 1997). The second addresses the relationship between national culture and individual entrepreneurial characteristics (McGrath et al., 1992; Thomas and Mueller, 2000), and the third, of less relevance in the present context, the impact of culture on corporate entrepreneurship. As noted above this literature draws heavily on Hofstede's taxonomy of dimensions of culture: individualism-collectivism, uncertainty avoidance, power-distance and masculinityfemininity (Hofstede, 1980), and studies have tended to hypothesise that entrepreneurship is more strongly associated with cultures which support individualism, low levels of uncertainty avoidance (less risk aversion), low levels of power-distance and high in masculinity. However this focus obscures deeper issues of how cultural norms arise and how cultural institutions and heritage might interact to generate a particular configuration of dimensions of cultural. Culture (formation of motives, values and beliefs, cognitive processes) might be 
interpreted as moderating the relationship between institution context and entrepreneurial activity and outcomes (Hayton et al. 2002; Freytag and Thurik 2010). The formation of religious beliefs and values and the operation of religious institutions and organisations potentially play both a critical role in determining the institution context and in the moderation process.

A much longer developed and substantial literature relates to the question of the relationship between economic development and religion. This is also of relevance to the present discussion. The Weberian hypothesis (Weber, 1904) that Protestant Christianity (or more specifically Calvinism) caused the rise of capitalist enterprise is perhaps better understood as highlighting a possible element in the causal process between deeply held religious belief and certain types of action, including those in the economic sphere, possibly acting through the impact of individual religiosity on wider society (Davie, 2007). Over the last 30 years or more a dominant perspective informing the development of sociology of religion has been that of secularization (Dobbelaere, 1981). Although the precise interpretation of this phenomenon is contested, it suggests the demise of any clear causal association between religion, both as individual belief and a source of institutional structure, and wider socio-economic development. An apparent association between declining religious belief and activity, particularly in the developed world, and economic growth over the last century might be interpreted through this lens. Subsequent scholarship has, however, sought to reassess the secularization hypothesis, particularly when viewed from a global rather than western perspective.

Secularization, as a concept, may be multi-faceted (Dobbelaere, 1981), covering institutions, practices and social marginalization. Trends in religious belief and activity across the globe are not uniform, and causal processes between religion and indicators of socio- 
economic development more complex than initially assumed. Secularization may operate at the level of the degree of societal influence exerted by religious institutions, but this is not necessarily inconsistent with declining levels of personal religious commitment (Berger, 1999). Furthermore religious institutions may adapt to secularisation rather than simply cease to exist. Key critics of secularization have highlighted these points. Some religious practices have been observed as being on the rise. The rapid growth in Pentecostal forms of Protestant Christianity in both Latin America and Africa, and the importance of the Roman Catholic church in post-transition Eastern Europe have been explored as key examples (Martin, 1991, 2002). Berger (1999) questions the implicit association between modernization and decline of religion in the secularization hypothesis, highlighting the persistence of religious practice and institutions in many parts of the world, not least as expressed through the growth of evangelicalism in North American Christianity, as well as in significant parts of the global "south".

The relationship between religion and economic development has attracted some limited attention from economists. The prevailing view is that of religious participation as rational choice (Warner, 1993; Iannaccone, 1998). Whereas the secularization hypothesis focuses on the demand side of the religious market, the rational choice literature introduces greater supply-side focus (Finke and Iannaconne, 1993; Iannaccone and Stark, 1994; McCleary and Barro, 2006a, 2006b). A key hypothesis in this work has been the importance of religious diversity (or "competition”) as feature of societies where religious activity appears to remain strong. Competitive forces in the religious "market" ensure that religious organizations work harder to provide value for members and prospective members, and in consequence may demand and obtain greater levels of commitment (Iannaconne, 1998). Evidence for such "market forces” may be found in indicators of religious pluralism - the extent to which a particular society supports a range of religious adherence, rather than 
favouring one particular religious group, or limiting the free development of religion through forms of state or societal regulation. The notion of "salvific merit" may also play a part in some religious value systems, and might find expression in the possible linkage in the minds of adherents between religious commitment and personal economic prosperity (McCleary and Barro, 2006a; Attanasi and Yong, 2012). As well as offering an explanation for religion being the dependent variable in the religion-economic development relationship, this literature also addresses potential causation in the reverse direction (McCleary and Barro, 2006b). A positive association may indicate that religion raises the social acceptability of entrepreneurial activity, by inculcating incentives to accumulate wealth and property and a sense of personal responsibility, as well as providing valuable forms of social capital through trust-building, networking and cultural identity (Guiso et al., 2003; 2006; Licht and Siegel, 2006). Particular forms of religious adherence appear to be associated with stronger motivation to acquire education (Lehrer, 2004). However set against this is the possibility that the time commitment demanded of religious adherents reduces labour supply, and may promote greater asceticism and denial of materialism. Different forms of religion and religion belief patterns may have different effects.

Aside from economic (cost-benefit) considerations which might arguably lie behind individual choice to participate in religious activity and organizations, research from a psychological perspective focuses on questions of individual identity and sense of calling (Heslam, 2013). Religious adherence and identity may serve to "sanctify" particular psychological goals and thus raise self-efficacy (McCulloch and Willoughby, 2009). However, the task of identifying particular psychological traits with entrepreneurship is an exercise that has been heavily criticised (Gartner, 1988; Aldrich, 1990), and may not readily extend to uncovering any overlap between those traits which are associated with entrepreneurship and religious adherence. The role of religion in promoting particular 
individual values and behavioural norms is associated with the role and operation of organizational and societal norms.

An institutional economics perspective on the role of religions, and particularly religious organizations, is that they may act across various dimensions in a similar fashion to other societal institutions. Religious institutions may strengthen and support clearly defined property rights, through providing moral force to support the rule of law (Acemoglu and Johnson, 2003). Economic benefits flow through reduced transactions costs. Religious institutions may also provide an institutional context for entrepreneurial networking and social capital building, which is distinct from market-based relationships (Granovetter, 1973), and may be particularly effective where state governance systems are weak (Licht and Siegel, 2006). Reputational bonding (Siegel, 2005) may serve as an important entrepreneurial strategy to signal trustworthiness with suppliers and customers, through social embeddedness (Granovetter, 1985; Aldrich and Zimmer, 1986). Membership of a religious organization may further facilitate the entrepreneur to embed within a dense social network. Social capital may form from a variety of sources (Portes and Sensenbrenner, 1993), including value introjection (being born into a particular group identity), reciprocity exchange, bonded communality (shared experiences of common events) and enforceable trust. It has been argued that the literature on entrepreneurship has emphasised the second and fourth of these, at the expense of research on the first and third (Licht and Siegel, 2006).

For the purposes of further investigation, a number of possible research questions for investigation are proposed. The first concerns the general question of whether there is in fact an association between religious participation (as a proxy for religiosity) and entrepreneurship, as discussed and suggested in these disparate literature streams: 
H1: There is a positive association between levels of religious participation and levels of entrepreneurial activity across different economies.

Religion and religious organizations may play a very significant role in intergenerational transmission of values and in creating social solidarity. Forms of developing religious activity, which involve strong emphases on the establishment of behavioural norms and on shared but distinct experience, may have a particular role to play. One such development, which has attracted considerable attention from leading sociologists of religion, is the development through the $20^{\text {th }}$ century of evangelical, charismatic and pentecostal movement (EPCM) Christianity in its various global manifestations (Martin, 1990; 1999; 2011; Berger, 2001; Heslam, 2013). Although precise definitions of these groupings are subject to discussion and debate, this form of Christianity is commonly thought to be share commonalities in both doctrine and practice. Problems of definition and identification arise because it may transcend traditionally identified and measured denominational groupings. It is often, although not exclusively, associated with values of strong personal motivation and responsibility, sometimes in the context of a "material prosperity gospel” (Meyer, 2010). ${ }^{1}$ In turn these values may be supportive of individual and collective entrepreneurial effort, either for personal gain or for social motives, resulting from stronger self-control or self-regulation (Haynes, 1995; Coleman, 2000; McCullough and Willoughby, 2009; Anderson et al., 2010).

Growth in EPCM Christianity, particularly in the global south may have been facilitated by the spread of democracy and the retreat of the state from regulating religion and media, into the latter of which EPCM groups may be quick to move (Meyer, 2010). By contrast hierarchical forms of religious organization, particular where they may be closely

\footnotetext{
${ }^{1}$ As Meyer (2010) notes, the impact of this may not be clear cut, as it may be associated with corruption, theft and illegal forms of consumerism and self-enrichment, justified on grounds of religious guidance.
} 
aligned to other state institutional arrangements, appear to be associated with greater organizational centralization (Bloom et al., 2009). This association may in turn imply discouragement towards more decentralised and entrepreneurial economic activity. This discussion is summarised in the following hypothesis:

H2: a) Particular forms of religious belief and practice are more supportive of, and therefore positively associated with levels of entrepreneurial activity;

b) in particular EPCM religious activity, because of its potential association with greater individual self-reliance and support for material prosperity as a sign of divine favour, is associated with higher entrepreneurial activity.

As already noted the direction of causation in the religion-economic development association is open to question (McCleary and Barro, 2006b). This has implications for any association between religion and entrepreneurship, because of the possible association between entrepreneurship (as a source of innovation) and economic development (Wennekers and Thurik, 1999; Carree and Thurik, 2003; Acs and Storey, 2004; Wong et al. 2005; Audretsch et al. 2006). Space precludes a detailed discussion of the complexities that might lie behind any association. For present purposes it is important to note that the possibility of an association between entrepreneurship and economic development implies that the level and rate of economic development might mediate the impact of religion:

H3: Because of potential association between religious activity and levels of economic prosperity, the association with levels of entrepreneurial activity is mediated by economic growth and prosperity.

There is one further important control factor to consider in the entrepreneurshipreligion relationship, namely the role of state and societal institutions. The "market for 
religion” literature proposes that state regulation of religion (which may take the form of circumscribing some institutions and activities but subsidising others) affects the nature of the religious “offer” (Finke and Iannaconne, 1993; Iannaconne and Stark, 1994; McCleary and Barro, 2006b). As a result the quality of religious "services” may decline and the influence of religious organizations on wider society may wane as a result. However, it is also noted that whereas membership may decline, there is no reason why falling levels of religious belief may necessarily follow (Davie, 1994). On the other hand regulation of religion is also offered as an explanation for the secularization hypothesis (Gill, 1999). Previous research on the economic development-religion relationship has investigated controlling for the impact of state and societal regulation (McCleary and Barro, 2006, 2006b). Thus a further hypothesis is proposed:

H4: The association between religion and entrepreneurial activity is mediated by prevailing state and societal attitudes towards (regulation of) religious activity, and the extent to which a society is revealed to support religious pluralism.

In summary it seems possible the range and type of religious activity observed across societies may influence levels of entrepreneurial intent and activity. In the particular this discussion has highlighted a number of themes through which religion and entrepreneurship might be interconnected, including hierarchical control of religion (and conversely pluralism in religious expression and activity), the role of religion in the promotion of particular cognitive characteristics and personal values; the promotion of social capital, and the reduction of transactions costs. This implies a need to focus on different types of religious experience. Previous literature (particularly on religion and economic development) appears to have addressed this in a rather superficial manner. 


\section{Methodology and data}

Previous research which focuses explicitly on the relationship between religion and entrepreneurship is rather scarce, and fragmentary both in terms of conceptual development and in terms of empirical analysis. Three types of study exist, and to some extent these mirror the more general discussion above. One, mirroring the first research theme above, examines the relationship between entrepreneurship and national level indicators of culture and social capital (Shane, 1993; Davidsson and Wiklund, 1997; Kwon and Arenius, 2010). A second type mirrors the second research theme above and looks within a particular national context at correlation between individual entrepreneurial activity and individual religious affiliation (Drakopoulou Dodd and Seaman, 1998; Audretsch et al., 2007, Nunziata and Rocco, 2011; Supphellen et al. 2012). A third type adopts qualitative methods or discursive analysis to examine specific national case-studies (for example Anderson et al. 2000; Basu and Altinay, 2002; Tong, 2012).

The previous section points strongly to a range of arguments that would support the investigation of proposed research questions relating entrepreneurial activity to religious activity at the societal level. This is because entrepreneurial decisions are influenced by the contribution of religious institutions and activities to the prevailing social and cultural milieux, as much as by personal religious affiliation or commitment. In short the literature described in the previous section focuses rather more strongly on the sociological aspects of religion (value transmission, networking and trust building, reputational bonding) than on the influence of religion on individual psychological and cognitive traits. This favours a research methodology based on investigating associations between religion and entrepreneurial activity at the level of the society or nation as the unit of observation. 
The methodology adopted here, therefore, is a quantitative one based on the linkage of information from various national level data sources. This is chosen, at this stage, on grounds of potential generalizability of conclusions, and in preference to, say, an approach based on a range of detailed societal case studies. However, such an approach based on investigating associations between national level indicators of entrepreneurial and religious activity is adopted at the expense of being able to provide detailed analysis of potential causal processes. The methodology adopted uses multiple regression analysis to control for the risk of identifying a spurious association which results from common covariance with other indicators, predominantly measures of national economic development (H3). This is because economic development and religious participation and structure may be significant correlated (McCleary and Barro, 2006a, 2006b; Attanasi and Yong, 2012). Previous research also strongly suggests a link between levels of economic development and entrepreneurship (Wennekers and Thurik, 1999; Audretsch et al. 2006; Audretsch, 2007;)

International comparative data on religious activity are readily available through surveys such as the World Values Survey and from a range of other secondary sources collated by the Association of Religious Data Archives. However such data sources typically reported membership levels of broad religious and denominational groupings, and fail to take account of the importance (within Christianity) of trans-denominational blocs who may share common value frameworks and theological outlooks, as well as similarities in institutional governance structures. The EPCM bloc or blocs fall specifically into this category. Once source, which does provide data on these blocs, collated from a wide range of national-level sources and contacts, is Mandryk (2010). This is a periodically updated compendium produced primarily as a resource for Christian churches, and compiles data drawn from international surveys, notably the World Christian Database (www.worldchristiandatabase.org), supplemented by intra-country denominational statistics 
and extensive personal correspondence and questionnaire material obtained from local sources. Percentage affiliation estimates are provided for all major world religions, including an estimate of “non-religious”. Mandryk (2010, pp. xxx-xxxiii) operationalizes, as far as possible, consistent definitions for denominational and trans-denominational Christian blocs across countries.. Six Christian denominational blocs are defined: Protestant, Independent/Indigenous, Anglican, Catholic, Orthodox, Marginal and Unaffiliated. The “Marginal” bloc includes groups such as Mormons and Jehovah's Witnesses. A further “double-affiliated” category is also defined to account for multiple affiliations, for example Catholics in Latin America who may also attend “new” Pentecostal denominational meetings. Mandryk (2010) also provides data on three "transbloc" groupings; Evangelicals, Charismatics and Pentecostals. These groupings are not mutually exclusive. Charismatics and Evangelicals are intersecting definitions, and Pentecostals are defined as lying within the union of the two other definitions. The intersection of all provides an estimate of the total EPCM bloc. Data for 226 nations are available and all data relate to the position in 2010.

These data are matched to data from the 2011 and 2012 Global Entrepreneurship Monitor surveys (Kelley et al., 2012; Roland Xavier et al., 2013), which, when combined, provide data for a sub-sample of 74 countries. Where both years are available the 2012 data are used. Table 1 provides summary information on the data for religious groupings. Christian denominational membership is divided into three groups. The first is "hierarchical", representing those denominations in which church governance is through a formal, generally episcopal hierarchy. The main members of this group are Roman Catholics, for whom membership across the full sample averages 29\%. Anglicanism although significant in Anglo-Saxon societies is much smaller globally as is Eastern Orthodox Christianity. The second group are Protestant denominations, excluding Anglicans. This group includes various forms of Methodism, Baptists, Presbyterians and Lutherans, as well as a wide range of 
smaller denominations. Across the sample membership averages 15\%. The final group described as "independents" includes those who are members of a wide range of new (nontraditional denominations) including new church networks. Globally this group are highly heterogeneous, although there may be significant overlap with the EPCM "transblocs". The largest of these intersecting groups are "evangelicals" who average almost $10 \%$ of the population of the countries in the sample. Of the non-Christian religions, Muslims are by some considerable margin the largest, averaging 22\% across the sample. Variance is high across countries, and the percentage is very high is some countries notably in the Middle East and North Africa. Those professing no religion average 7.6\% across the sample. Absence of stated religious affiliation tends to be highest in European advanced economies and in some former Communist societies. For example this group accounts for $34 \%$ of the population in the UK, and 19\% in Russia. The final row of the Table reports sample summary information for a religious pluralism index, constructed using a Herfindahl-Hirschman index. ${ }^{2}$ Subsample summary information is also reported for those countries for which GEM data is available. There are some differences between the averages for this sub-sample and the full sample, but these are generally not large. GEM appears to slightly better represent "Christian" countries rather than "Muslim" ones, and those with a higher non-religious population.

Table 2 reports summary information on the key GEM indicators of entrepreneurial activity used in the research. These indicators are generally familiar to entrepreneurship

\footnotetext{
2 This measure, commonly used as a indicator of industrial concentration, is constructed as the sum of the squared population shares of the religious groups for each country (excluding the intersecting "transblocs"). The inverse of this measure is sometimes used to indicate the hypothetical number of groups that would hold if all groups were of equal size. The sample average of 0.46 suggests that the average country would have two equally sized religious groups.
} 
researchers. ${ }^{3}$ Total Entrepreneurial Activity (TEA) is the percentage of the population aged between 18 and 64 who involved in setting up a new business or have a business which has been trading and paying its owners for less than 42 months. This averages almost $13 \%$ across the available sample. The Nascent Entrepreneurship Rate (NER) is the percentage of the population actively involved in setting up a business or running a business that has been paying its owners for less than three months. This averages $7.4 \%$ across the sample. Necessity entrepreneurship is the proportion of population who are involved in TEA but because they had no other option for work. Improvement-driven entrepreneurship is the proportion who are involved in TEA to pursue an opportunity to improve their independence or income over any alternative. Across the sample improvement-driven entrepreneurship is almost twice as important as necessity-driven. Histograms to illustrate the distribution of these measures across the sample are shown in Figure 1.

Table 2 also reports summary data on indicators of governmental regulation, through laws and policies, and wider social regulation of religion, often by other religions, obtained via ARDA from Grim and Finke (2006). It also includes summary data on median population age and levels and growth in real gross domestic product per capita. The regulation of religion indicators are variables defined on a scale from 1 (low) to 10 (high), and along with population median age data are reported in the cross-national data files of the Association of Religion Data Archives (ARDA). ${ }^{4}$ GDP data are taken from the Penn World Tables 7.1 data set. $^{5}$

Because the available data contain a number of intersecting measures of the various "transbloc” groupings that comprise EPCM Christianity, a scale measure is constructed. Data

\footnotetext{
${ }^{3}$ See http://www.gemconsortium.org/docs/download/414 (accessed 8-April-2014)

${ }^{4}$ See http://www.thearda.com/Archive/CrossNational.asp (accessed 8-April-2004)

5 Centre for International Comparisons at the University of Pennsylvania, see https://pwt.sas.upenn.edu (accessed 8-April-2014)
} 
investigation revealed that an appropriate scale can be constructed from the four percentage shares for the "evangelical”, “charismatic”, "Pentecostal” and "unaffiliated” groups. Table 3 reports the diagnostics for this scale. The overall Cronbach alpha statistic for the four items is 0.825, suggesting a high level of reliability. ${ }^{6}$ This scale measure is then used in the analysis of the relationship between EPCM Christianity and levels of entrepreneurial activity. For other religious groupings population share measures are used.

\section{Findings}

\section{a) bivariate correlation}

Table 4 reports pairwise correlation coefficients between each of the four indicators of national entrepreneurial activity and the various population religion shares, as well as the religious pluralism index and, for completeness, the two indicators of governmental and societal regulation of religion. The table reveals sizeable and statistically significant positive correlations between the population share of independent Christian denominations and all four measures of entrepreneurial activity. Even larger and more significant correlations are found between the EPCM scale measure and the four measures of entrepreneurial activity. The only other statistically significant correlations with religion shares are found for the population share of the non-religious. However in this case the correlations are negative - a greater share of non-religious in the population is associated with lower levels of entrepreneurial activity.

\footnotetext{
${ }^{6}$ The "marginal" grouping was omitted from the scale, as its inclusion worsened the alpha score. Given the nature of this grouping, it may be capturing a rather different set of religious traditions.
} 
Table 4 also shows that there is a positive association between religious pluralism and entrepreneurial activity. These correlations are statistically significant, although in the case of necessity-driven entrepreneurship the correlation is a little lower and significant only at 8 per cent. There is also evidence in the table of a strong negative association between greater social regulation of religion and entrepreneurial activity on all four measures. Negative associations are also observed for government regulation of religion - however this is only statistically significant for the nascent entrepreneurship and opportunity-driven entrepreneurship rates.

These findings provide some support for H1, although they suggest that there is a far from uniform relationship between religious affiliation and entrepreneurial activity. Particular forms of religion (H2a), and greater freedom of religious membership and variety of expression, are associated with entrepreneurial activity. In particular these findings provide strong prima facie support for H2b - namely an association between EPCM Christianity and entrepreneurial activity at societal level.

\section{b) regression analysis}

As Figure 1 shows there is skewness in the distributions of the four entrepreneurship indicators. This absence of normality means that conventional least squares regression is likely to be problematic. In consequence, in order to investigate multivariate associations and to address the hypotheses concerning the mediating impact of the level and rate of economic development and the degree of religious pluralism or regulation, a median regression approach is used. This uses absolute least squares and estimates the multivariate relationship 
at the 50th percentile (quantile) of the sample distribution (Koenker, 2005). ${ }^{7}$ Results are reported in Table 5. For each GEM measure three model specifications are reported. Specification (a) reports a regression of the association between the GEM indicator and the shares of the religious groups, along with the Herfindahl measure of pluralism. Specification (b) replaces the independent Christian share with the EPCM scale variable and additionally includes economic prosperity level and growth, median population age, and regulation of religion indicators as control variables. The large number of variables in specification (b) appears to induce a high degree of multicollinearity. So specification (c) reports a preferred stepwise reduction that retains significant variables without impairing goodness of fit too far.

Specification (a) results suggest that there are few strong associations between religion population shares and the GEM measures, with the notable exception of the share of independent Christians. Here the associations are very strong, although lower but still statistically significant for necessity entrepreneurship. Also for necessity entrepreneurship there is a strong positive association with the degree of religious pluralism. Necessity-driven entrepreneurship appears to be positively associated with Muslim population share, and with the share of "hierarchical" forms of Christianity. There is some evidence of a positive association between Buddhism and entrepreneurship - improvement driven entrepreneurship, significant at 7\%, in specification (a) and TEA in specification (b). The negative association with higher levels stated non-religiosity, found in the bivariate results in Table 4, do not remain here. Specification (a) appears to offer some support for H1, but it is clear that this only holds for some, but not all, of religion (H2a). In specification (b) some of the marginal associations for religion cease to be significant. The one significant control factor in specification (b) appears to be median population age. Older populations are less

\footnotetext{
${ }^{7}$ A log transformation of the entrepreneurship indicators provides results that support similar conclusions. However median regression results are reported on preference, as the technique is less restrictive. The other results are available on request.
} 
entrepreneurial. For necessity-driven entrepreneurship there is evidence that economic prosperity and growth exercise a mediating impact. Necessity entrepreneurship is associated with poorer, but faster growing societies. Inclusion of these control effects appears to reduce sharply the size and significance of the association with Islamic adherence for this form of entrepreneurship.

In specification (c) the removal of other insignificant religious share variables has the impact of significantly sharpening the association with EPCM Christianity. An increase in this scale variable by 0.1 (around 1.5 standard deviations) is associated with a 5 percentage point increase in total entrepreneurial activity, with a 3 percentage point increase in nascent entrepreneurship and a 19 percentage point increase in improvement-driven entrepreneurship. This appears to confirm support for H2b. There is no significant association with necessitydriven entrepreneurship. Population age has an offsetting effect. Higher rates of GDP growth have a positive effect. The EPCM association appears to hold, even controlling for a positive association between GDP growth rates and the various measures of entrepreneurial activity (H3).

There is no evidence in these results of any association between entrepreneurial activity and social regulation of religion. There is however quite strong evidence for an association with governmental regulation of religion. Although there is no significant association with the TEA measure, there is, in columns 2(c), 3(c) and 4(c) of Table 5, evidence of significant negative associations between all the other indicators of entrepreneurship and higher government regulation of religion. Higher levels of religious pluralism appear to support both necessity-drive and improvement-driven entrepreneurship. So although high population involvement in ECPM forms of Christianity might be associated 
with improved rates of entrepreneurship, this can be offset by state involvement in regulating religion (H4).

\section{Discussion}

The background literature described earlier offers pointers to a number of mechanisms through which entrepreneurship and religious affiliation and activity might be associated. The results presented here provided an initial, macro-level investigation of these questions. They do point to some significant bivariate associations between consistently measured national-level indicators of entrepreneurial activity and indicators of the scale of particular forms of religious affiliation. These associations appear to remain in a multivariate framework in which allowance is made for various potentially important control factors. In particular the association between indicators of entrepreneurial activity, particularly positive opportunity-focused forms of activity, and rates of affiliation to EPCM Christianity seems quite robust. Associations in the data appear to exist between other forms of religious affiliation, and possibly no religious affiliation, but these do not appear to be particularly robust to alternative specifications of the potential relationship.

These results therefore raise the question of what might be particular about EPCM Christianity, such that it appears to inspire higher levels of entrepreneurial activity amongst its adherents or amongst wider society. The analysis presented in this paper is not able to address underlying causal processes - it has highlighted a potential association that clearly merits further attention. As noted earlier explanations for such a relationship might include individual psychological factors such as the sanctification of personal career goals or the desire for material success (“prosperity gospel”), thus raising self-efficacy. Broader cultural or institutional explanations might include the support to entrepreneurial social and 
networking capital which is provided by dense networks of like-minded religious adherents who share common values, but which also provide a more effective basis for trust-building and the sanctioning of social penalties for breaking trust.

Although a significant association is observed between EPCM Christianity and total, nascent and improvement-driven entrepreneurship rates, no significant association is observed in the regression analysis with necessity-driven entrepreneurship. However there is an association with greater religious pluralism. One potential explanation is that this might indicate a tendency for minority religions, while being allowed to co-exist in a pluralist society, are nevertheless pushed into entrepreneurial activity, due to social exclusion. Such minorities might well be coincident with particular ethnicities in some societies.

Levels of economic prosperity and rates of economic growth appear to exert a significant mediating effect on the religion-entrepreneurship nexus. Entrepreneurship and economic prosperity are associated. However these findings are not consistent with a secularization hypothesis, which would predict that any religion-entrepreneurship relationship was an artefact of the fact that rates of entrepreneurship appear to be higher in lower income but faster growing societies, and that lower income societies have higher levels of religious adherence. The religion-EPCM association appears robust to controlling for level and rate of economic development. The association is therefore more than just a consequence of being in a poorer country with a younger demographic profile.

One further question remaining in these findings is that of why government regulation of religion appears to exert a negative mediating influence but social regulation does not. Grim and Finke (2006) define social regulation as "the restrictions placed on the practice, profession, or selection of religion by other religious groups, associations, or the culture at large” (p.8). Such restrictions appear not to be as effective as those that are supported by 
official regulation or registration. Certain governments in certain contexts may formally frown on the activities of particular religious institutions, and therefore indirectly impede the entrepreneurial activities of particular groups. However forms of social opprobrium, which are not supported by the force of law or regulation, do not extend to entrepreneurial activity. Social movements, as opposed to governments, appear to be capable of recognising the value of entrepreneurial activity in these contexts. In passing it should be noted again here that hierarchical Christianity appears to be associated with higher level of necessity-driven entrepreneurship. Such forms may impose greater uniformity of belief and practice on adherents and may in turn suppress "free" entrepreneurial choice as an expression of individual preference, with the consequent effect that where entrepreneurship does arise it is chosen reluctantly due to lack of other livelihood alternatives.

It is important to highlight the limitations of the present analysis. Correlations observed in macro-level data shed limited and inconclusive light on underlying causal processes. It hardly needs to be emphasised that much further work is required to look at the underlying "whys" and both qualitative and quantitative work at a lower levels of analysis (the individual or group, rather than nation) to investigate in further detail the robustness of these prima facie conclusions.

\section{Conclusion}

This paper is concerned with an issue that attracted very little attention from entrepreneurship researchers - namely whether there is a connection between religious affiliation and activity and rates of entrepreneurship. Religion remains a very significant global cultural phenomenon in all its various guises. Sociologists of religion now question the once dominant hypothesis that economic growth is associated with rising secularization. The 
literature and background material reviewed in this paper suggests a range of perspectives of the relationship between religious adherence and economic activity, and therefore potential connections with entrepreneurship. Psychological perspectives focus the potential role of religion in "sanctifying" personal goals and values. Economic perspectives focus on the vibrancy of the "market" for religion and propose that a stronger impact on economic development might follow from more effective, “consumer-focused” religious institutions. Governmental regulation of religion may harm such impacts. Institutional, transaction costbased perspectives may offer the richest potential vein of research, by focusing on the role of religious adherence and institutions on the creation of social capital, trust and inter-personal networking, as well as the cultural transmission and dissemination of common values that may provide a supportive environment in which entrepreneurship might flourish.

The findings presented in this paper are based on a macro-level investigation of associations between key entrepreneurial indicators (drawn from the Global Entrepreneurship Monitor) and aggregate indicators of national religious affiliation and regulation. Two particular conclusions stand out. The first is that newer forms of Christianity, characterised here as the evangelical, pentecostal and charismatic movement, appear to be associated with higher rates of entrepreneurial activity. Such forms of Christianity are documented as growing fast, particularly but not exclusively, in less developed parts of the world. They may typically demand much higher levels of personal commitment and piety, than are present in traditional, hierarchical forms of Christianity, that may spill over more extensively into other aspects of life. They might, as a result, more effectively embed forms of social networks and trust-building that support successful entrepreneurial activity. The second conclusion is that where government seek to regulate religious activity, or where levels of religious pluralism are lower, this may in fact impair or hinder some of these potential mechanisms. However these may exist causal explanations for the religion-entrepreneurship nexus that need urgently 
to form the subject of a much wider research agenda, encompassing the full range of disciplinary perspectives on entrepreneurship, beyond the preliminary discussion and assessment contained in this paper. 


\section{Bibliography}

Acemoglu, D. and Johnson, S.H. (2003), "Unbundling institutions”, National Bureau of Economic Research Working Paper, No. 9934, Cambridge MA: NBER.

Aldrich, H.E. (1990), "Using an ecological perspective to study organizational founding rates”, Entrepreneurship Theory and Practice, 14(3): 7-24.

Aldrich, H.E. and Zimmer, C. (1986), "Entrepreneurship through social networks", in D. Sexton and R. Smiler (eds.), The Art of Science of Entrepreneurship, New York: Ballinger.

Anderson, A., Bergunder, M., Droogers, A., and van der Laan, C. (2010) (eds). Studying Global Pentecostalism: Theories and Methods, Berkeley CA: University of California Press.

Anderson, A.R., Drakopoulou-Dodd, S.L. and Scott, M.G. (2000), "Religion as an environmental influence on enterprise culture: the case of Britain in the 1980s", International Journal of Entrepreneurial Behaviour and Research, 6(1): 5-20.

Acs, Z. and Storey, D. (2004), “Introduction: entrepreneurship and economic development”, Regional Studies, 38(8): 871-877.

Attanasi, K. and Yong, A. (2012), Pentecostalism and Prosperity, New York NY: Palgrave Macmillan.

Audretsch, D.B. (2007), The Entrepreneurial Society, New York, Oxford UP.

Audretsch, D.B., Keilbach, M. and Lehmann, E. (2006), Entrepreneurship and Economic Growth, New York: Oxford UP.

Audretsch, D.B., Boente, W. and Tamvada, J.P. (2007), "Religion and entrepreneurship", Centre for Economic Policy Research Discussion Paper No. 6378, London: CEPR,

Basu A. and Altinay E. (2002), "The interaction between culture and entrepreneurship in London’s immigrant businesses”, International Small Business Journal, 20: 371-94

Berger, P (ed.) (1999), The Desecularization of the World: Resurgent Religion and World Politics, Grand Rapids MI: Eerdmans Publishing.

Bloom, N., Sadun, R. and Van Reenan, J. (2009), "The organization of firms across countries”, National Bureau of Economic Research Working Paper No. 15129, Cambridge MA: NBER.

Carree, M. A. and Thurik, R. (2003), 'The Impact of Entrepreneurship on Economic Growth”, in David B. Audretsch and Zoltan J. Acs (eds.), Handbook of Entrepreneurship Research, Boston/Dordrecht:Kluwer Academic Publishers, pp. 437-471.

Coleman, S. (2000). The Globalisation of Charismatic Christianity: Spreading the Gospel of Prosperity. Cambridge: Cambridge University Press.

Davidsson, P. (1995), "Culture, structure and regional levels of entrepreneurship". Entrepreneurship and Regional Development, 7. 41-62. 
Davidsson, P. and Wiklund, J. (1997), "Values, beliefs and regional variations in new firm formation rates”. Journal of Economic Psychology, 18, 179-199.

Davie, G. (1994), Religion in Britain since 1945: Believing without belonging. Oxford: Blackwell.

Davie, G. (2007), The Sociology of Religion, London: Sage.

Dobbelaere, K. (1981), “Secularization: a multidimensional concept”, Current Sociology, 20(2): 1-216.

Drakopoulou-Dodd, S. and Seaman, P. (1998), "Religion and enterprise: an introductory exploration”, Entrepreneurship Theory and Practice, 71-87.

Finke, R. and Iannaccone. L.R. (1993), "Supply-side explanations for religious change." The Annals of the American Academy of Political and Social Sciences, 527, 27-39.

Freytag, A. and Thurik, A.R. (eds.) (2010), Entrepreneurship and Culture, Proceedings of 2005 Conference at Max Planck Institute of Economics, Jena.

Gartner, W. (1988), “'Who is an entrepreneur?' Is the wrong question”, American Journal of Small Business, 11-32

Gill, A. (1999), "Government regulation, social anomie, and Protestant growth in Latin America: A cross-national analysis”, Rationality and Society, 11:287-316.

Granovetter, M.S. (1973), “The strength of weak ties”, American Journal of Sociology, 78(6): 1360-1380.

Granovetter, M.S. (1985), "Economic action and social structure: the problem of embeddedness”, American Journal of Sociology, 91(3): 481-510.

Grim, B.J. and Finke, R. (2006), "International religion indexes: government regulation, government favoritism and social regulation of religion", Interdisciplinary Journal of Research on Religion, 2 (Baylor University, TX)

Guiso, L., Sapienza, P., and Zingales, L. (2003), "People’s opium? Religion and economic attitudes”, Journal of Monetary Economics, 50: 225-282.

Guiso, L., Sapienza, P., and Zingales, L. (2006), “Does culture affect economic outcomes?”, Journal of Economic Perspectives, 20(2): 23-48.

Haynes, J. (1995), "Popular religion and politics in sub-Saharan Africa", Third World Quarterly, 16 (1): 89-108.

Hayton, J.C., George, G. and Zahra, S.A. (2002), "National culture and entrepreneurship: a review of behavioural research”, Entrepreneurship Theory and Practice, 26(4): 33-53.

Heslam, P. (2013), “Christianity and the prospects for development in the global south” in P. Oslington (ed.), Oxford Handbook of Christianity and Economics, Oxford; Oxford UP (forthcoming). 
Hofstede, G. (1980), Culture's consequences: International differences in work related values. Beverly Hills, CA: Sage.

Iannaccone, L.R. (1998), "Introduction to the economics of religion”, Journal of Economic Literature, 36(3): 1465-1496.

Iannoccone, L.R. and Stark, R. (1994) "A supply-side interpretation of the secularization hypothesis”, Journal for the Scientific Study of Religion, 33:76-88.

Kelley, D.J., Singer, S., Herrington, M. (2012) Global Entrepreneurship Monitor: 2011 Global Report, Global Entrepreneurship Research Association.

Koenker, R. (2005), Quantile Regression, Cambridge, CUP.

Kwon, S-W. and Arenius, P. (2010), "Nations of entrepreneurs: a social capital perspective”, Journal of Business Venturing, 25: 315-330.

Lehrer, E. (2004). "Religion as a determinant of economic and demographic behavior in the United States". Population and Development Review, 30, 707-726

Licht, A.N. and Seigel, J.I. (2006), “The social dimensions of entrepreneurship”, in M. Casson and B. Yeung (eds.), Oxford Handbook of Entrepreneurship, Oxford: Oxford University Press.

Mandryck, J. (2010), Operation World, $7^{\text {th }}$ Ed., Westmont IL: Intervarsity Press.

Martin, D. (1990), Tongues of Fire: The Explosion of Protestantism in Latin American, Oxford: Blackwell.

Martin, D. (1991), “The secularization issue: prospect and retrospect”, British Journal of Sociology, 42: 466-74.

Martin, D. (1999), "The protestant upsurge and its political implications", in (ed.) P.L. Berger, The Desecularization of the World: Resurgent Religion and World Politics, Grand Rapids MI: Eerdmans, pp. 37-50.

Martin, D. (2002), Pentecostalism: The World their Parish, Oxford: Blackwell.

Martin, D. (2011) The Future of Christianity: Reflections on Violence and Democracy, Religion and Secularization, Farnham: Ashgate.

Meyer, B. (2010), "Pentecostalism and globalization” in Anderson, A., Bergunder, M., Droogers, A., and van der Laan, C. (eds). Studying Global Pentecostalism: Theories and Methods, Berkeley CA: University of California Press, pp. 113-129.

McCleary, R.M. and Barro, R.T. (2006a), "Religion and political economy in an international panel”, Journal for the Scientific Study Religion, 45(2): 149-175.

McCleary, R.M. and Barro,, R.T. (2006b), "Religion and economy”, Journal of Economic Perspectives, 20(2): 49-72.

McClelland, D.C. (1961), The Achieving Society, New York: Free Press. 
McCloskey, D. (2007), The Bourgeois Virtues: Ethics for an Age of Commerce, Chicago: Chicago University Press.

McCullough, M.E. and Willoughby, B.L.B. (2009), "Religion, self-regulation, and selfcontrol: associations, explanations, and implications”, Psychological Bulletin, 235 (1): 69-93.

McGrath, G.R., Macmillan, I., Tang, E A-Y, and Tsai, W. (1992), "Does culture endure or is it malleable? Issues for entrepreneurial economic development”, Journal of Business Venturing, 7(6): 441-458.

Nunziata, L. and Rocco, L. (2011), "The implications of cultural background on labour market choices; the case of religion and entrepreneurship”, IZA Institute for Labor Discussion Paper No. 6114, Bonn: IZA.

Portes, A. and Sensenbrenner, J. (1993), "Embeddedness and immigration: notes on the social determinants of economic action”, American Journal of Sociology, 98: 1320-1350.

Roland Xavier, S., Kelley, D., Kew, J., Herrington, M. and Vorderwulbecke, A. (2013), Global Entrepreneurship Monitor: 2012 Global Report, Global Entrepreneurship Research Association

Schumpeter, J, (1934), The Theory of Economic Development, Cambridge MA: Harvard University Press.

Shane, S. (1993), "Cultural influences on national rates of innovation”, Journal of Business Venturing, 8: 59-73.

Supphellen, M., Haugland, S, and Oklevik, O. (2012), "Entrepreneurial orientation, selfefficacy, and religious attitudes in small third-world enterprises", unpublished paper, Norwegian School of Economics and Business Administration.

Thomas, A.S. and Mueller, S.L. (2000), “A case for comparative entrepreneurship: Assessing the relevance of culture”, Journal of International Business Studies, 31: 591-609.

Tong, J. K-C. (2012), Overseas Chinese Christian Entrepreneurs in Modern China: a case study of the influence of Christian ethics on business life, London and New York: Anthem Press.

Warner, R.S. (1993). "Work in progress toward a new paradigm for the sociology of religion in the United States,” American Journal of Sociology, 98(5): 1044-93.

Weber, M. (1905), The Protestant Ethic and the Spirit of Capitalism, (translated P. Baehr and G.C. Wells, 2002, Harmondsworth: Penguin).

Wennekers, S. and Thurik, R. (1999), "Linking entrepreneurship and economic growth", Small Business Economics, 13(1): 27-55.

Wong, P.K., Ho, Y.P. and Autio, E. (2005), "Entrepreneurship, innovation and economic growth: evidence from GEM data”, Small Business Economics, 24:335-350. 
Table 1: Religious Groups and Diversity

\begin{tabular}{|l|c|c|c|c|}
\hline Percentage & Mean - all & Std Dev -all & $\begin{array}{c}\text { Mean - } \\
\text { GEM } \\
\text { sample }\end{array}$ & $\begin{array}{c}\text { Std Dev - } \\
\text { GEM } \\
\text { sample }\end{array}$ \\
\hline $\mathrm{N}$ & 226 & & 74 & \\
\hline Christian groups: & & & & \\
\hline All Christian & & & & \\
\hline a) Hierarchical & 37.4 & 32.3 & 40.2 & 32.7 \\
\hline - Anglican (Episcopalian) & 2.9 & 8.8 & 2.2 & 7.3 \\
\hline - Catholic & 29.1 & 31.7 & 31.7 & 32.7 \\
\hline - Orthodox & 5.2 & 17.1 & 6.3 & 18.3 \\
\hline $\begin{array}{l}\text { Protestant } \\
\text { (excl. Anglican) }\end{array}$ & 15.3 & 20.9 & 14.6 & 20.0 \\
\hline c) Independent & 6.5 & 10.5 & 6.4 & 10.9 \\
\hline Christian EPCM “transblocs”: & & & & \\
\hline - Unaffiliated & 3.2 & 5.7 & 3.4 & 5.5 \\
\hline - Marginal & 1.6 & 4.4 & 1.0 & 1.2 \\
\hline - Evangelicals & 9.6 & 10.7 & 8.8 & 10.0 \\
\hline - Charismatic & 7.6 & 9.1 & 7.7 & 9.4 \\
\hline - Pentecostal & 4.0 & 5.7 & 3.9 & 5.6 \\
\hline Muslim & & & & \\
\hline Hindu and Sikh & 22.0 & 34.7 & 16.7 & 30.5 \\
\hline Buddhist & 2.0 & 8.8 & 1.2 & 4.3 \\
\hline Jewish & 3.6 & 14.2 & 3.8 & 14.0 \\
\hline Chinese/Asian religions & 0.5 & 5.1 & 1.3 & 8.8 \\
\hline Other religions & 1.4 & 7.3 & 1.7 & 7.9 \\
\hline Non-religious & 3.9 & 7.8 & 2.3 & 4.8 \\
\hline Religious Pluralism Index & 0.459 & 0.229 & 0.480 & 0.219 \\
\hline
\end{tabular}

Source: author's own calculations from GEM data and Mandryk (2010) religious affiliation data. 
Table 2: Entrepreneurial Activity, Economic and Political Development

\begin{tabular}{|l|l|l|}
\hline & Mean & Std Dev \\
\hline $\mathrm{N}$ & 74 & \\
\hline GEM Total Entrepreneurial Activity & $12.9 \%$ & 8.7 \\
\hline GEM Nascent Entrepreneurship Rate & $7.4 \%$ & 5.0 \\
\hline GEM Necessity-driven Entrepreneurship Rate & $3.6 \%$ & 3.4 \\
\hline GEM Improvement-driven Entrepreneurship Rate & $6.1 \%$ & 4.3 \\
\hline & & \\
\hline Government regulation of religion index 2008 & 1.90 & 2.77 \\
\hline Social regulation of religion index 2008 & 4.03 & 3.41 \\
\hline & & \\
\hline Median population age 1990 & 27.0 & 7.4 \\
\hline Real GDP per capita in 2000 (US\$) & 15,187 & 13,112 \\
\hline Growth in real GDP per capita 2000-2010\% & 31.0 & 27.3 \\
\hline & & \\
\hline
\end{tabular}

Source: author's own calculations from GEM, Penn World Tables and ARDA data.

Table 3: EPCM Christianity scale

\begin{tabular}{|l|c|c|}
\hline Item: population share of & Item total correlation & alpha \\
\hline Unaffiliated & 0.560 & 0.917 \\
\hline Evangelical & 0.935 & 0.760 \\
\hline Charismatic & 0.947 & 0.732 \\
\hline Pentecostal & 0.909 & 0.738 \\
\hline & & \\
\hline Scale & & 0.855 \\
\hline Scale mean & & 0.060 \\
\hline $\mathrm{N}=74$ & & \\
\hline
\end{tabular}

Source: author's own calculations. 
Table 4: Pairwise correlations between GEM indicators and size of religious groups/religious regulation

\begin{tabular}{|c|c|c|c|c|}
\hline $\begin{array}{l}\text { Correlation coefficient } \\
\text { (signif. level), } \mathrm{N}=74\end{array}$ & TEA & NER & $\begin{array}{l}\text { Necessity- } \\
\text { driven }\end{array}$ & $\begin{array}{l}\text { Improvement- } \\
\text { driven }\end{array}$ \\
\hline Hierarchical Christian & $\begin{array}{l}0.056 \\
(0.635)\end{array}$ & $\begin{array}{l}0.099 \\
(0.402)\end{array}$ & $\begin{array}{l}0.039 \\
(0.739)\end{array}$ & $\begin{array}{l}-0.016 \\
(0.896)\end{array}$ \\
\hline Protestant Christian & $\begin{array}{l}0.124 \\
(0.291)\end{array}$ & $\begin{array}{l}0.135 \\
(0.251)\end{array}$ & $\begin{array}{l}0.047 \\
(0.692)\end{array}$ & $\begin{array}{l}0.175 \\
(0.135)\end{array}$ \\
\hline Independent Christian & $\begin{array}{l}0.373 \\
(\mathbf{0 . 0 0 1 )}\end{array}$ & $\begin{array}{l}0.423 \\
(\mathbf{0 . 0 0 0 )}\end{array}$ & $\begin{array}{l}0.291 \\
(\mathbf{0 . 0 1 2})\end{array}$ & $\begin{array}{l}0.376 \\
(\mathbf{0 . 0 0 1 )}\end{array}$ \\
\hline EPCM scale & $\begin{array}{l}0.575 \\
(\mathbf{0 . 0 0 0 )}\end{array}$ & $\begin{array}{l}0.565 \\
(\mathbf{0 . 0 0 0 )}\end{array}$ & $\begin{array}{l}0.459 \\
(0.000)\end{array}$ & $\begin{array}{l}0.584 \\
(0.000)\end{array}$ \\
\hline Muslim & $\begin{array}{l}-0.099 \\
(0.403)\end{array}$ & $\begin{array}{l}-0.164 \\
(0.163)\end{array}$ & $\begin{array}{l}0.048 \\
(0.685)\end{array}$ & $\begin{array}{l}-0.134 \\
(0.254)\end{array}$ \\
\hline Hindu/Sikh & $\begin{array}{l}-0.118 \\
(0.316)\end{array}$ & $\begin{array}{l}-0.113 \\
(0.339)\end{array}$ & $\begin{array}{l}-0.152 \\
(0.194)\end{array}$ & $\begin{array}{l}-0.045 \\
(0.701)\end{array}$ \\
\hline Buddhist & $\begin{array}{l}-0.065 \\
(0.584)\end{array}$ & $\begin{array}{l}-0.106 \\
(0.370)\end{array}$ & $\begin{array}{l}-0.123 \\
(0.298)\end{array}$ & $\begin{array}{l}0.029 \\
(0.810)\end{array}$ \\
\hline Non-religious & $\begin{array}{l}-0.370 \\
(\mathbf{0 . 0 0 8 )}\end{array}$ & $\begin{array}{l}-0.255 \\
(\mathbf{0 . 0 2 8})\end{array}$ & $\begin{array}{l}-0.340 \\
(0.003)\end{array}$ & $\begin{array}{l}-0.247 \\
(\mathbf{0 . 0 3 4 )}\end{array}$ \\
\hline Religious pluralism index & $\begin{array}{l}0.301 \\
(\mathbf{0 . 0 0 9 )}\end{array}$ & $\begin{array}{l}0.272 \\
(\mathbf{0 . 0 1 9 )}\end{array}$ & $\begin{array}{l}0.204 \\
(0.081)\end{array}$ & $\begin{array}{l}0.363 \\
(\mathbf{0 . 0 0 2 )}\end{array}$ \\
\hline $\begin{array}{l}\text { Government regulation of } \\
\text { religion index } 2008\end{array}$ & $\begin{array}{l}-0.161 \\
(0.171)\end{array}$ & $\begin{array}{l}-0.238 \\
(\mathbf{0 . 0 4 1})\end{array}$ & $\begin{array}{l}-0.061 \\
(0.604)\end{array}$ & $\begin{array}{l}-0.202 \\
(0.085)\end{array}$ \\
\hline $\begin{array}{l}\text { Social regulation of religion } \\
\text { index } 2008\end{array}$ & $\begin{array}{l}-0.341 \\
(\mathbf{0 . 0 0 3 )}\end{array}$ & $\begin{array}{l}-0.358 \\
(\mathbf{0 . 0 0 2 )} \\
\end{array}$ & $\begin{array}{l}-0.290 \\
(\mathbf{0 . 0 1 2})\end{array}$ & $\begin{array}{l}-0.334 \\
(\mathbf{0 . 0 0 4 )}\end{array}$ \\
\hline
\end{tabular}

Source: author's own calculations. 
Table 5: Multivariate median regression results

\begin{tabular}{|c|c|c|c|c|c|c|c|c|c|}
\hline & 1(a) & 1(b) & $1(c)$ & $2(a)$ & $2(b)$ & $2(c)$ & $3(a)$ & $3(b)$ & $3(c)$ \\
\hline $\begin{array}{l}\text { Coefficient } \\
\text { (p-value) }\end{array}$ & TEA & TEA & TEA & NER & NER & NER & $\begin{array}{c}\text { Necessity- } \\
\text { driven }\end{array}$ & $\begin{array}{l}\text { Necessity- } \\
\text { driven }\end{array}$ & $\begin{array}{c}\text { Necessity- } \\
\text { driven }\end{array}$ \\
\hline \% Hierarchical Christian & $\begin{array}{c}5.431 \\
(0.526)\end{array}$ & $\begin{array}{c}5.889 \\
(0.227)\end{array}$ & & $\begin{array}{c}1.704 \\
(0.715)\end{array}$ & $\begin{array}{c}3.214 \\
(0.454)\end{array}$ & & $\begin{array}{c}2.379 \\
(0.101)\end{array}$ & $\begin{array}{c}1.299 \\
(0.088)\end{array}$ & $\begin{array}{c}1.034 \\
(0.048)\end{array}$ \\
\hline \% Protestant Christian & $\begin{array}{c}7.266 \\
(0.484) \\
\end{array}$ & $\begin{array}{c}5.705 \\
(0.341) \\
\end{array}$ & & $\begin{array}{c}3.502 \\
(0.541) \\
\end{array}$ & $\begin{array}{c}3.731 \\
(0.479) \\
\end{array}$ & & $\begin{array}{c}2.140 \\
(0.229) \\
\end{array}$ & $\begin{array}{c}1.562 \\
(0.110) \\
\end{array}$ & $\begin{array}{c}1.138 \\
(0.154) \\
\end{array}$ \\
\hline \% Independent Christian & $\begin{array}{l}37.295 \\
(\mathbf{0 . 0 3 1 )}\end{array}$ & & & $\begin{array}{l}26.260 \\
(\mathbf{0 . 0 0 9 )}\end{array}$ & & & $\begin{array}{c}5.761 \\
(0.050)\end{array}$ & & \\
\hline EPCM scale & & $\begin{array}{l}40.282 \\
(0.043) \\
\end{array}$ & $\begin{array}{l}49.583 \\
(\mathbf{0 . 0 0 0 )} \\
\end{array}$ & & $\begin{array}{l}11.749 \\
(0.518) \\
\end{array}$ & $\begin{array}{l}26.674 \\
(\mathbf{0 . 0 0 1 )} \\
\end{array}$ & & $\begin{array}{l}-2.436 \\
(0.450) \\
\end{array}$ & \\
\hline \% Muslim & $\begin{array}{c}6.363 \\
(0.532) \\
\end{array}$ & $\begin{array}{c}2.530 \\
(0.653) \\
\end{array}$ & & $\begin{array}{c}1.709 \\
(0.752) \\
\end{array}$ & $\begin{array}{l}-1.132 \\
(0.816)\end{array}$ & & $\begin{array}{c}4.603 \\
(\mathbf{0 . 0 0 7 )} \\
\end{array}$ & $\begin{array}{c}1.088 \\
(0.235) \\
\end{array}$ & \\
\hline \% Hindu/Sikh & $\begin{array}{c}-33.885 \\
(0.270)\end{array}$ & $\begin{array}{c}-20.318 \\
(0.291)\end{array}$ & & $\begin{array}{c}-8.344 \\
(0.674)\end{array}$ & $\begin{array}{c}-4.750 \\
(0.699)\end{array}$ & & $\begin{array}{c}-8.688 \\
(0.118)\end{array}$ & $\begin{array}{c}3.550 \\
(0.260)\end{array}$ & \\
\hline \% Buddhist & $\begin{array}{c}8.806 \\
(0.537) \\
\end{array}$ & $\begin{array}{r}13.582 \\
(\mathbf{0 . 0 1 6 )} \\
\end{array}$ & & $\begin{array}{c}6.483 \\
(0.215) \\
\end{array}$ & $\begin{array}{c}4.326 \\
(0.377)\end{array}$ & & $\begin{array}{c}3.296 \\
(0.045)\end{array}$ & $\begin{array}{c}0.250 \\
(0.775) \\
\end{array}$ & \\
\hline \% Non-religious & $\begin{array}{c}-4.216 \\
(0.744)\end{array}$ & $\begin{array}{c}7.164 \\
(0.358)\end{array}$ & & $\begin{array}{c}-2.810 \\
(0.814)\end{array}$ & $\begin{array}{c}3.818 \\
(0.578)\end{array}$ & & $\begin{array}{l}-4.215 \\
(0.053)\end{array}$ & $\begin{array}{c}-1.106 \\
(0.414)\end{array}$ & \\
\hline Pluralism & $\begin{array}{c}7.524 \\
(0.399) \\
\end{array}$ & $\begin{array}{c}1.476 \\
(0.764) \\
\end{array}$ & & $\begin{array}{c}1.180 \\
(0.814) \\
\end{array}$ & $\begin{array}{c}0.587 \\
(0.898) \\
\end{array}$ & & $\begin{array}{c}3.304 \\
(\mathbf{0 . 0 3 0}) \\
\end{array}$ & $\begin{array}{c}2.793 \\
(\mathbf{0 . 0 0 1 )} \\
\end{array}$ & $\begin{array}{c}2.017 \\
(\mathbf{0 . 0 0 8 )} \\
\end{array}$ \\
\hline Government Regulation Index & & $\begin{array}{c}-0.394 \\
(0.371)\end{array}$ & & & $\begin{array}{l}-0.334 \\
(0.401)\end{array}$ & $\begin{array}{l}-0.330 \\
(0.061) \\
\end{array}$ & & $\begin{array}{c}-0.197 \\
(\mathbf{0 . 0 0 8 )}\end{array}$ & $\begin{array}{l}-0.163 \\
(\mathbf{0 . 0 2 0})\end{array}$ \\
\hline Social Regulation Index & & $\begin{array}{c}0.221 \\
(0.472) \\
\end{array}$ & & & $\begin{array}{c}0.107 \\
(0.704) \\
\end{array}$ & & & $\begin{array}{c}-0.063 \\
(0.193) \\
\end{array}$ & \\
\hline GDP per head $2000 \$$ & & $\begin{array}{c}0.451 \\
(0.669) \\
\end{array}$ & & & $\begin{array}{l}-0.276 \\
(0.757)\end{array}$ & & & $\begin{array}{l}-0.510 \\
(\mathbf{0 . 0 0 1 )}\end{array}$ & $\begin{array}{l}-0.422 \\
(\mathbf{0 . 0 1 8}) \\
\end{array}$ \\
\hline $\begin{array}{l}\text { \% Change in GDP per head } \\
2000-10\end{array}$ & & $\begin{array}{c}0.054 \\
(0.184)\end{array}$ & $\begin{array}{c}0.070 \\
(\mathbf{0 . 0 0 0 )}\end{array}$ & & $\begin{array}{c}0.018 \\
(0.564)\end{array}$ & $\begin{array}{l}-0.980 \\
(\mathbf{0 . 0 1 5 )}\end{array}$ & & $\begin{array}{c}0.018 \\
(0.002)\end{array}$ & $\begin{array}{c}0.015 \\
(0.004)\end{array}$ \\
\hline Median population age 1990 & & $\begin{array}{l}-0.643 \\
(\mathbf{0 . 0 0 8 )}\end{array}$ & $\begin{array}{l}-0.279 \\
(\mathbf{0 . 0 0 0 )}\end{array}$ & & $\begin{array}{l}-0.337 \\
(0.104)\end{array}$ & $\begin{array}{l}-0.100 \\
(0.269)\end{array}$ & & $\begin{array}{l}-0.166 \\
(\mathbf{0 . 0 0 0 )}\end{array}$ & $\begin{array}{l}-0.179 \\
(\mathbf{0 . 0 0 0 )} \\
\end{array}$ \\
\hline Pseudo R-squared & 0.144 & 0.404 & 0.355 & 0.174 & 0.340 & 0.355 & 0.127 & 0.384 & 0.368 \\
\hline
\end{tabular}


Table 5: continued

\begin{tabular}{|c|c|c|c|}
\hline & $4(a)$ & $4(b)$ & $4(c)$ \\
\hline $\begin{array}{l}\text { Coefficient } \\
\text { (p-value) }\end{array}$ & $\begin{array}{l}\text { Improvement- } \\
\text { driven }\end{array}$ & $\begin{array}{l}\text { Improvement- } \\
\text { driven }\end{array}$ & $\begin{array}{l}\text { Improvement- } \\
\text { driven }\end{array}$ \\
\hline \% Hierarchical Christian & $\begin{array}{c}1.699 \\
(0.467)\end{array}$ & $\begin{array}{c}1.937 \\
(0.321)\end{array}$ & \\
\hline \% Protestant Christian & $\begin{array}{c}2.537 \\
(0.350)\end{array}$ & $\begin{array}{c}2.661 \\
(0.306)\end{array}$ & \\
\hline \% Independent Christian & $\begin{array}{l}16.854 \\
(0.001)\end{array}$ & & \\
\hline EPCM scale & & $\begin{array}{l}18.302 \\
(0.069)\end{array}$ & $\begin{array}{l}18.708 \\
(0.000)\end{array}$ \\
\hline \% Muslim & $\begin{array}{c}1.812 \\
(0.502)\end{array}$ & $\begin{array}{c}2.182 \\
(0.362)\end{array}$ & \\
\hline \% Hindu/Sikh & $\begin{array}{l}-3.363 \\
(0.729)\end{array}$ & $\begin{array}{l}-7.596 \\
(0.185)\end{array}$ & \\
\hline \% Buddhist & $\begin{array}{c}1.113 \\
(0.774) \\
\end{array}$ & $\begin{array}{c}5.646 \\
(0.066) \\
\end{array}$ & \\
\hline \% Non-religious & $\begin{array}{l}-0.729 \\
(0.835)\end{array}$ & $\begin{array}{c}1.987 \\
(0.580)\end{array}$ & \\
\hline Pluralism & $\begin{array}{c}5.132 \\
(\mathbf{0 . 0 2 8})\end{array}$ & $\begin{array}{c}2.928 \\
(0.166)\end{array}$ & $\begin{array}{c}1.869 \\
(0.093)\end{array}$ \\
\hline Government Regulation Index & & $\begin{array}{l}-0.345 \\
(0.050)\end{array}$ & $\begin{array}{l}-0.259 \\
(0.004)\end{array}$ \\
\hline Social Regulation Index & & $\begin{array}{l}-0.002 \\
(0.985) \\
\end{array}$ & \\
\hline GDP per head $2000 \$$ & & $\begin{array}{r}0.445 \\
(0.235) \\
\end{array}$ & \\
\hline $\begin{array}{l}\text { \% Change in GDP per head } \\
2000-10\end{array}$ & & $\begin{array}{c}0.445 \\
(0.235)\end{array}$ & $\begin{array}{c}0.021 \\
(\mathbf{0 . 0 0 5 )}\end{array}$ \\
\hline Median population age 1990 & & $\begin{array}{l}-0.328 \\
(\mathbf{0 . 0 0 2 )} \\
\end{array}$ & $\begin{array}{l}-0.210 \\
(\mathbf{0 . 0 0 0 )}\end{array}$ \\
\hline Pseudo R-squared & 0.168 & 0.387 & 0.359 \\
\hline
\end{tabular}

Note: italic denotes statistical significance at or below $10 \%$, bold italic at or below $5 \%$.

Source: author's own calculations. 
Figure 1: GEM Entrepreneurship Indicators 2011-2012
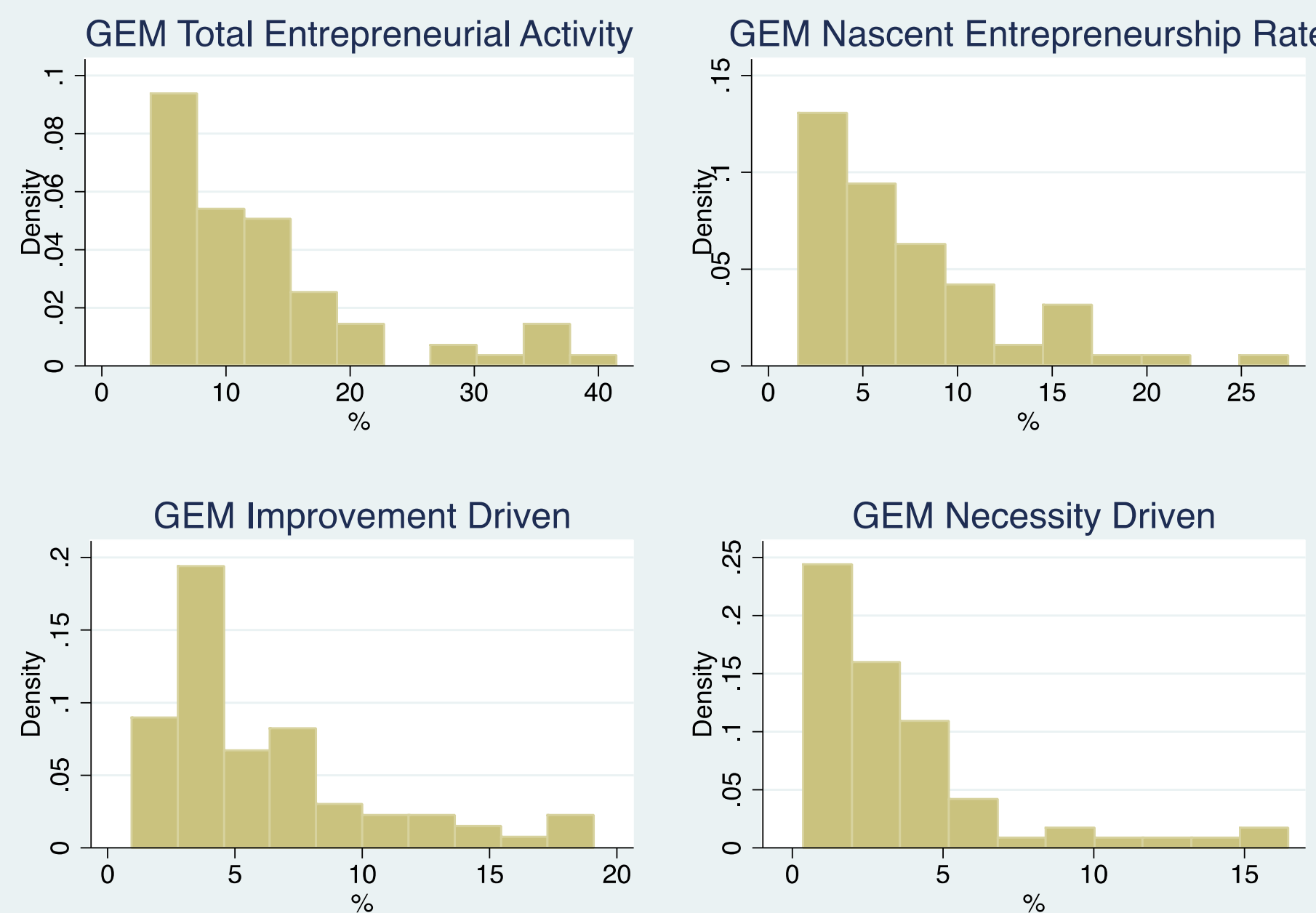